\title{
Effect of Exercise Duration on Klotho and GluN2B Gene Expressions in Hippocampus of Wistar Rats with Moderate Intensity Exercise
}

\author{
Hanna Goenawan, ${ }^{1}$ Bela Ita Karina, ${ }^{3}$ Titing Nurhayati, ${ }^{2,3}$ Julia Windi Gunadi, ${ }^{4}$ Setiawan, ${ }^{2,3}$ \\ Ronny Lesmana ${ }^{2,3}$ \\ ${ }^{1}$ Physiology Division, Department of Biomedical Sciences Faculty of Medicine Universitas Padjadjaran, Indonesia, \\ ${ }^{2}$ Undergraduate Program Medical Doctor, Faculty of Medicine Universitas Padjadjaran, Indonesia, ${ }^{3}$ Physiology \\ Molecular Laboratory, Biological Activity Division, Central Laboratory, Universitas Padjadjaran, Indonesia. \\ ${ }^{4}$ Department of Physiology Maranatha Christian University, Bandung, Indonesia
}

\begin{abstract}
Exercise could delay the degeneration process by increasing Klotho, which is an endogen antioxidant. Klotho protects against oxidative damages, regulates hippocampal synaptic plasticity, and enhances GluN2B expression. This study aimed to analyze the effect of 14-day and 8-week moderate-intensity exercise on Klotho and GluN2B mRNA expressions in rat hippocampus. This study was an animal experimental study using Wistar rats that was performed from June to September 2019 at the Central Laboratory, Universitas Padjadjaran, Indonesia. Rats were divided into 4 groups: control (14-day control and 8-week control) and exercise group (14-day exercise and 8-week exercise). The exercise groups ran at a moderate intensity $(20 \mathrm{~m} / \mathrm{min})$ for $30 \mathrm{~min} /$ day, $5 \mathrm{x} /$ week. Hippocampus was then subjected to klotho and GluN2B gene expression analysis. The exercise groups showed a higher Klotho expression, both in 14 days $(0.844 \pm 0.124$ vs. $1.057 \pm 0.013)$ and 8 weeks $(0.897 \pm 0.072$ vs. $1.380 \pm 0.168)$ although statistically insignificant $(\mathrm{p}=0.24)$. No difference in GluN2B gene expression was observed between control and exercise groups on 14 days $(1 \pm 0.09$ vs. $1.22 \pm 0.09)$ and 8 weeks $(1.24 \pm 0.03$ vs. $1.38 \pm 0.05 ; p=0.11)$. In conclusion, 14-day and 8-week moderate-intensity exercise did not alter Klotho and GluN2B expressions in rat hippocampus.
\end{abstract}

Key words: Duration, Exercise, GluN2B, hippocampus, Klotho

\section{Pengaruh Durasi Olahraga terhadap Perubahan Ekspresi Gen Klotho dan GluN2B di Hipokampus Tikus Galur Wistar yang Mendapatkan Perlakuan Lari Intensitas Sedang}

\begin{abstract}
Abstrak
Olahraga dapat menghambat proses degenerasi saraf dengan meningkatkan salah satu antioksidan endogen, yaitu Klotho. Klotho dapat melindungi sel neuron dari kerusakan oksidatif dan meningkatkan sinaptik plasticity pada hipokampus. Penelitian ini bertujuan untuk melihat pengaruh olahraga lari pada hewan coba pada 14 hari dan 8 minggu terhadap perubahan ekspresi gen Klotho and GluN2B di hipokampus. Penelitian ini merupakan penelitian eksperimental dilaksanakan pada bulan Juni hingga September 2019 di Laboratorium Sentral Universitas Padjadjaran. Penelitian ini menggunakan tikus jantan galur wistar. Tikus dibagi menjadi 4 kelompok perlakuan dan kontrol. Olahraga dilakukan dengan treadmill tikus, kecepatan $20 \mathrm{~m} / \mathrm{min}$, 30 menit perhari selama 5 kali perminggu. Kemudian, mRNA otak digunakan untuk PCR dengan menggunakan primer klotho dan GluN2B. Hasil penelitian menunjukkan bahwa tidak terdapat perbedaan yang bermakna $(\mathrm{p}=0.24)$ pada ekspresi gen Klotho pada 14 hari $(0.844 \pm 0.124$ vs $1.057 \pm 0.013)$ dan 8 minggu $(0.897 \pm 0.072$ vs $1.380 \pm 0.168)$ antara kelompok kontrol dan kelompok lari. Ekspresi gen dari GluN2B juga tidak menunjukkan perbedaan yang signifikan ( $\mathrm{p}=0.11)$ pada 14 hari ( $1 \pm 0.09$ vs $1.22 \pm 0.09)$ dan 8 minggu ( $1.24 \pm 0.03$ vs $1.38 \pm 0.05)$. Simpulan, bahwa 8 minggu olahraga tidak meningkatan ekspresi Klotho dan GluN2B yang signifikan.
\end{abstract}

Kata kunci: Durasi, olahraga, GluN2B, hipokampus, Klotho

Corresponding Author: Hanna Goenawan, Physiology Division, Department of Biomedical Sciences Faculty of Medicine Universitas Padjadjaran, Jalan Raya Jatinangor KM 21.6, Jatinangor, West Java, Indonesia, Email: hanna@unpad.ac.id 


\section{Introduction}

The elderly population is increasing along with technological advances in the health sector. Nevertheless, an increase in life expectancy can increase the prevalence of degenerative diseases. One of the degenerative diseases that increases in prevalence is dementia. A global study on dementia showed that the number of dementia patients worldwide has reached around 43.8 million in 2016. Increase in life expectancy without a good quality of life could increase the global burden. ${ }^{1}$ Therefore, interventions are needed to prevent dementia.

The risk factors for dementia are divided into unmodifiable and modifiable factors. Unmodifiable factors of dementia are age, family history, and genetics, such as the presence of apolipoprotein E allele. Meanwhile, the modifiable factors dementia are current smoking, social engagement, year education, and lack of physical activity. ${ }^{2}$

Exercise has a potential effect as a neuroprotector. Aerobic exercise like running for 8 weeks prevents neuronal degeneration by reducing lipid peroxidation and preventing ROS production. ${ }^{3,4}$ Another study in a rat model of Alzheimer's disease showed that physical exercise prevents memory deterioration in a rat model through the improvement of endogen antioxidants. $^{3}$

Klotho is known as an anti-aging gene in humans. ${ }^{4}$ In the brain, Klotho has been proven to be a neuroprotective agent and regulator of synaptic plasticity., ${ }^{4,5}$ Studies show that klotho interacts with Insulin Growth Factor-1 (IGF-1) to regulate $\beta$ amyloid by increasing its clearance via choroid plexus. ${ }^{6}$ It plays a role as a neuroprotective agent against neuronal oxidative damage induced by $\beta$ amyloid and glutamate by regulating thioredoxin/peroxiredoxin (Trx/Prx) system. ${ }^{4}$ Study shows that klotho could enhance GluN2B expression, an N-methyl-D-aspartate (NMDAR) subunit that plays an important role in learning and memory. ${ }^{7}$ Exercise could enhance klotho expression. ${ }^{8}$ Short duration of interval training has been proved to increase klotho expression in heart tissue of rat model of cardiac ischemia. On the other hand, moderate-intensity exercise upregulated the NMDRs subunit in the hippocampal area while high-intensity exercise suppressed NMDRs expression. ${ }^{9}$

Several studies have demonstrated a correlation between Klotho and GluN2B. A study from Dena B. Dubal et al. showed an increase of GluN2B in postsynaptic densities and enhanced
NMDAR long-term potentiation as a consequence of klotho elevation in human amyloid precursor protein (hAPP) mice. ${ }^{10}$ Long term potentiation is one of the synaptic plasticity forms which plays an important role in learning and memory. ${ }^{11}$

However, no study has compared the effect of exercise duration on Klotho and GluN2B expressions in the hippocampus. This study was conducted to compare the effects of 14 days and 8 weeks of exercise on hippocampal klotho and GluN2B in Wistar rats.

\section{Methods}

This was an experimental study on 36 male Wistar rats obtained from Biofarma Laboratory, Bandung, Indonesia at the age 10 weeks with a body weight of 201-250 grams. Rats were kept at room temperature with 12-hours light and dark cycle with food and water ad libitum. The animals were habituated on a treadmill for 2 weeks before treatment. The animal experiment was held at the Animal Laboratory of Physiology Division, Faculty of Medicine, Universitas Padjadjaran, and the Central Laboratory, Universitas Padjadjaran from June to September 2019. All experimental protocols had been approved by the Research Ethics Committee of Universitas Padjadjaran no 1237/UN6.KEP/EC/2019.

IDEA's treadmill machine for rats with five lanes was used. All animals were habituated on the treadmill machine for 2 weeks until achieving the desired speed. Rats ran on an individual lane for assigned speed (Control: 0 $\mathrm{m} / \mathrm{min}, 14$ days and 8 weeks groups: $20 \mathrm{~m} / \mathrm{min}$ ). Moderate intensity exercise was based on lactate threshold as described in a previous study.,12 Lactate threshold was reached on $20 \mathrm{~m} / \mathrm{min}$ treadmill exercise. Physical exercise duration was $30 \mathrm{~min} /$ day, 5 times a week for each group. Exercise periods were 14 days and 8 weeks of physical exercise treatment. ${ }^{9}$

After the physical exercise treatment, all rat groups were terminated under anesthesia. Rats were decapitated, the vital organ was isolated, and the brain was kept under cold temperature. Hippocampus was isolated from the cerebrum, kept in Eppendorf tubes, and stored in $-80^{\circ} \mathrm{C}$ until RNA isolation.

RNA was isolated from hippocampal tissue using TRIzol as a reagent (Thermo Fisher Scientific, Uppsala, Sweden). The sample was subjected to semi-quantitative PCR with One-Step RT PCR Kit (Bioline, London, UK) using the Sensoquest Labcycler Thermocycler 
H Goenawan etal.: Effect of Exercise Duration on Klotho and GluN2B Gene Expressions in Hippocampus of Wistar Rats with Moderate Intensity Exercise

Table Primer For PCR

\begin{tabular}{llcc}
\hline \multicolumn{1}{c}{ Gene } & \multicolumn{1}{c}{ Primer Sequence } & Tm & Product \\
\hline Klotho $^{12}$ & F: CTCTGAAAGCCTACGTGTTGG & $56^{\circ} \mathrm{C}$ & $275 \mathrm{bp}$ \\
& R: TAGAAACGAGATGAAGGCCAG & & $157 \mathrm{bp}$ \\
GluN2B $^{13}$ & F: GGCATTGCTATCCAAAAGGA & $61^{\circ} \mathrm{C}$ & \\
& R: GCTGCCCCCAACATATAGAA & & $177 \mathrm{bp}$ \\
GAPDH & F: GTTACCAGGGCTGCCTTCTC & $61^{\circ} \mathrm{C}$ & \\
& R: GATGGTGATGGGTTTCCCGT & & \\
\hline
\end{tabular}

Tm: Primer melting temperature, F: forward primer, R: reverse primer

(Genecraft, Koln, Germany). Primer sequences used in this study are presented in Table 1. Gel electrophoresis was performed after PCR and the gel band of each gene was visualized using Bluepad Dual Transilluminator BioDocAnalyze while the band thickness was quantified using Image J software (NIH, USA).

All statistical analyses were performed using IBM SPSS version 20.0 software. Data were served as means \pm standard error of means (Mean \pm SEM). Data analysis was started with the Shapiro-Wilk test to check normality and
Levene's test for homogeneity. This was then followed by the analysis on statistical difference among groups using One Way ANOVA and Least Significant Difference Test. In this study, a p-Value of $<0.05$ was considered statistically significant.

\section{Result}

To assess the effect of moderate-intensity exercise with two different durations on internal antioxidant gene expression, the Klotho gene
A

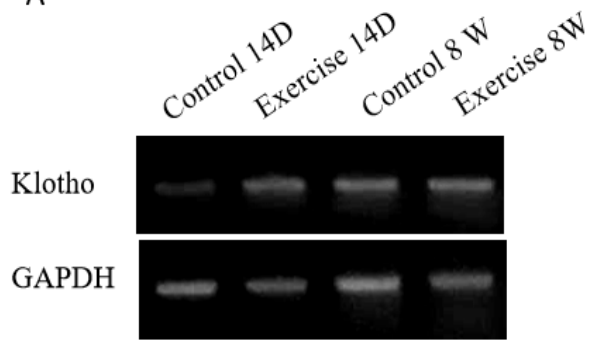

B

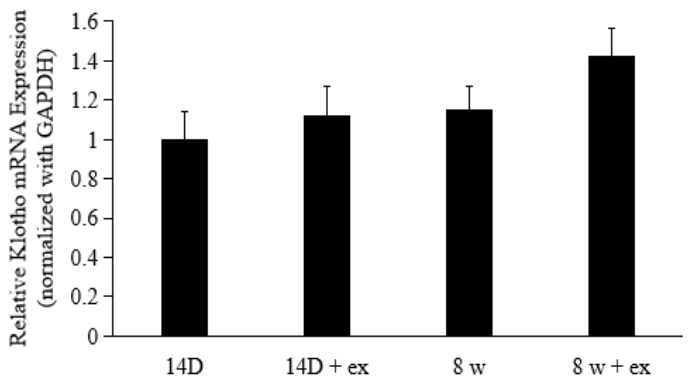

Figure 1 Klotho mRNA Band Expression

(A) Relative expression of klotho gene, normalized by GAPDH; (B) Data represent mean \pm SEM

A

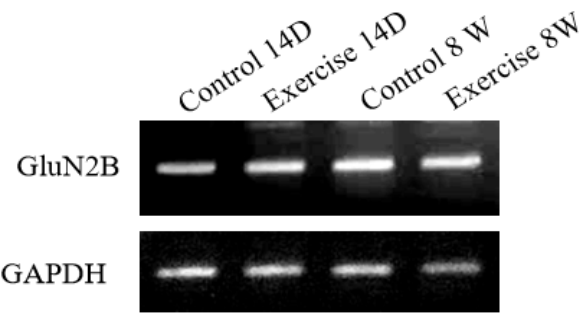

B

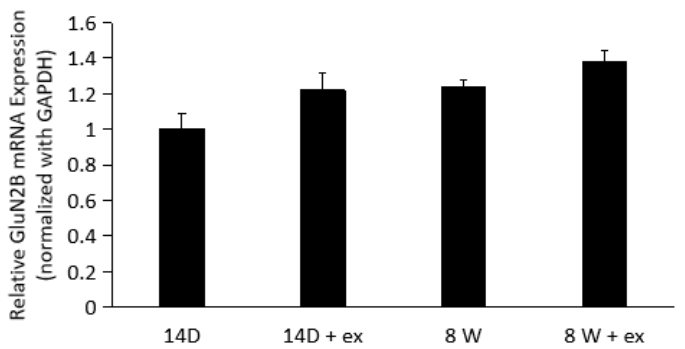

Figure 2 GluN2B Relative Gene Expression at 14 Days and 8 Weeks Exercise

(A) GluN2B expression was normalized with GAPDH; (B) Value is expressed as Mean \pm SEM 
expression was measured on day 14 and week 8 of the treatment period (Figure 1). Klotho mRNA bands are presented in Figure 1A. It was demonstrated that 14 days $(0.844 \pm 0.124$ vs $1.057 \pm 0.013)$ and 8 weeks $(0.897 \pm 0.072$ vs $1.380 \pm 0.168 ; p=0.24$ ) of exercise increased the Klotho level although not statistically significant (Figure 1B).

To investigate whether the Klotho increment affects the synaptic plasticity in different duration of exercise, the mRNA level of NMDAR subunit GluN2B in hippocampus was measured (Figure 2A). No change was observed in GluN2B expression among groups in 14 days of physical exercise duration $(1 \pm 0.09$ vs $1.22 \pm 0.09)$ and the prolonged duration of exercise until 8 weeks did not alter GluN2B gene expression compared to the control group $(1.24 \pm 0.03$ vs $1.38 \pm 0.05)$, with $\mathrm{p}=0.11$ (Figure 2B).

\section{Discussion}

Many previous studies have shown that exercise gives many benefits for humans. Exercise induces physiology responses by affecting homeostasis in the body. Exercise, especially exhaustive exercise, could damage tissue by producing excessive reactive oxygen species (ROS).$^{10}$ Nevertheless, moderate-to-high exercise could increase antioxidant results, resulting in elevation of ROS concentration which enhances physiological functioning. ${ }^{14}$

Regular exercise has multiple anti-aging effects on the body. Klotho is known as an antiaging gene, which is highly expressed in the brain and kidneys. ${ }^{3}$ Several studies show that klotho increases as a result of exercise. A study from Ji et al. showed that aerobic exercise could significantly increase klotho mRNA and protein in both rat's brain and kidney. ${ }^{8}$ During exercise, especially with moderate-to-high intensity, skeletal muscle generates Reactive Oxygen Species(ROS). Accumulation of ROS leads to tissue damage due to DNA and protein alteration. ${ }^{15}$ In a cell culture experiment, Klotho has the ability to prevent oxidation and dissociation. ${ }^{16}$ ROS disturbs neuronal signaling especially dopaminergic neurons through activating ROSsensitive apoptosis signal-regulating kinase -1 (ASK1)/p38. Klotho overexpression modulates the ASK1/p38 pathway, thus protects the dopamine neuron from ROS induce apoptosis. ${ }^{17}$

Aerobic exercise training for 48 weeks on rat model leads to higher klotho expression in brain and kidney. ${ }^{18} \mathrm{~A}$ previous study discovered that intermittent high-intensity exercise for 5 days induces klotho expressions in plasma. ${ }^{19}$ The results of this present study showed that no significant difference in Klotho expression between the 14-day and 8-week groups. Although insignificant, a higher Klotho expression level was found in the exercise group. Prolonged exercise duration (8 weeks) showed a higher Klotho expression compared to the 14 days exercise. Discrepancies identified in this study are possibly caused by stress oxidative level as the regulator of Klotho expression. Different intensity exercises and different duration produced various stress oxidative levels. It suggests training intensity combined with duration plays an important role in regulating klotho expressions.

Several studies have demonstrated a correlation between Klotho and GluN2B. A study from Dena B. Dubal et al. showed an increase of GluN2B in postsynaptic densities and enhanced NMDAR long-term potentiation as a consequence of Klotho elevation in human amyloid precursor protein (hAPP) mice. ${ }^{9}$ Two weeks of treadmill exercise upregulates the NMDARs receptor in mice model. ${ }^{20}$. In contrast, No difference in GluN2B gene expression was observed in this present study between 14 days and 8 weeks of exercise. These results correlate with Klotho expression in the hippocampus. It indicates that GluN2B expression is partly modified by Klotho expression. However, other forms of NMDAR receptor were not measured in this study; thus, further studies are needed to elucidate the correlation of exercise with other NMDAR receptors.

Certain limitations in this study should be considered. First, Klotho expression is regulated by stress oxidative level but this study did not observe oxidative stress level, ROS, or another endogenous antioxidant levels in relationship to Klotho expression. Second, only moderate intensity was used in this study that further studies are needed to reveal the effect of different intensity and duration of exercise on endogen antioxidant and synaptic plasticity.

In conclusion, 14 days and 8 weeks of moderate-intensity exercise does not change Klotho and GluN2B gene expression in the hippocampus of Wistar rats.

\section{References}

1. GBD 2016 Dementia Collaborators. Global, regional, and national burden of Alzheimer's 
H Goenawan etal.: Effect of Exercise Duration on Klotho and GluN2B Gene Expressions in Hippocampus of Wistar Rats with Moderate Intensity Exercise

disease and other dementias, 1990-2016: a systematic analysis for the Global Burden of Disease Study 2016. Lancet Neurol. 2019; 18(1): 88-106.

2. Schimidt HL, Garcia A, Izquierdo I, MelloCarpes PB, Carpes FP. Strength training and running elicit different neuroprotective outcomes in a $\beta$-amyloid peptide-mediated Alzheimer's disease model. Physiol Behav. 2019;206:206-12.

3. Kurucz A, Bombicz M, Kiss R, Priksz D, Varga B, Hortobágyi T, et al. Heme Oxygenase-1 activity as a correlate to exercise-mediated amelioration of cognitive decline and neuropathological alterations in an aging rat model of dementia. Biomed Res Int. 2018;2018(7212861):1-13.

4. Zeldich E, Harris DA, Liang J, Abraham CR, Tucker Zhou TB, Chen C-D, et al. The neuroprotective effect of klotho is mediated via regulation of members of the redox system. J Biol Chem. 2014;289(35):2470015.

5. Li Q, Vo HT, Wang J, Fox-Quick S, Dobrunz LE, King GD. Klotho regulates CA1 hippocampal synaptic plasticity. Neuroscience. 2017;347: 123-33.

6. Foster PP, Rosenblatt KP, Kuljiš RO. Exerciseinduced cognitive plasticity, implications for mild cognitive impairment and Alzheimer's disease. Front Neurol. 2011;2(28):1-15.

7. Dubal DB, Yokoyama JS, Zhu L, Broestl L, Worden K, Wang D, et al. Life extension factor klotho enhances cognition. Cell Rep. 2014;7(4):1065-76.

8. Hu F, Lao K, Luan J, Ji N, Wang W, Lv B, et al. Aerobic exercise stimulated Klotho upregulation extends life span by attenuating the excess production of reactive oxygen species in the brain and kidney. Exp Ther Med. 2018;16(4):3511-7.

9. Ren H, Yu X, Yu L, Zhang GY, Xie FH, Shi N et al. Effects of different training loads on emotional state and mRNA and protein expressions of N-Methyl-D-Aspartate receptor subunits, postsynaptic density 95, and kinesin family member 17 in hippocampus of rats. Med Sci Monit. 2017; 23: 4954-60.

10. Dubal DB, Yokoyama JS, Zhu L, Broestl L, Worden K, Wang D, et al. Life extension factor klotho enhances cognition. Cell Rep.2014;7(4):1065-76.
11. Ho VM, Lee J-A, Martin KC. The cell biology of synaptic plasticity. Science. 2011;334(6056):623-8.

12. Lesmana $R$, Iwasaki $T$, Iizuka $Y$, Amano I, Shimokawa N, Koibuchi N. The change in thyroid hormone signaling by altered training intensity in male rat skeletal muscle. Endocr J. 2016;63(8):727-38.

13. Rios R, Pineda C, Lopez I, Muñoz-Castañeda J, Rodriguez M, Aguilera-Tejero E, et al. Phosphorus restriction does not prevent the increase in fibroblast growth factor 23 elicited by high fat diet. PLoS ONE. 2018;13(6): e0198481.

14. Ji Y, Bai G, Cao G, and Traub RJ. Estradiol modulates visceral hyperalgesiabyincreasing thoracolumbar spinal GluN2B subunit activity in female rats. Neurogastroenterol Motil. 2015;27(6):775-86.

15. Parker L, Mcguckin TA, Leicht AS. Influence of exercise intensity on systemic oxidative stress and antioxidant capacity. Clin Physiol Funct Imaging. 2014;34(5):377-83.

16. Ung L, Pattamatta U, Carnt N, WilkinsonBerka JL, Liew G, White AJR. Oxidative stress and reactive oxygen species: A review of their role in ocular disease. Clin Sci. 2017;131(24):2865-83.

17. Brobey RK, Dheghani M, Foster PP, Kuro-O M, Rosenblatt KP. Klotho regulates 14-3-37 monomerization and binding to the ask1 signaling complex in response to oxidative stress. pLoS One. 2015;10(10):1-18.

18. Ji N, Luan J, Hu F, Zhao Y, Bosen Lv, Wang W, et al. Aerobic exercise-stimulated Klotho upregulation extends life span by attenuating the excess production of reactive oxygen species in the brain and kidney. Exp Ther Med. 2018;16(4):3511-7.

19. Ramez M, Rajabi H, Ramezani F, Naderi N, Darbandi-Azar A, Nasirinez F. The greater effect of high-intensity interval training versus moderate-intensity continuous training on cardioprotection against ischemia-reperfusion injury through Klotho levels and attenuate of myocardial TRPC6 expression. BMC Cardiovasc Disord. 2019;19:118.

20. Joon-Ki Park, Sam-Jun Lee, Tae-Won Kim. Treadmill exercise enhances NMDA receptor expression in schizophrenia mice. Exerc Rehabil. 2014;10(1):15-21. 